\title{
CONTROL OF AFLATOXINS IN THE FOOD INDUSTRY
}

\author{
E. HANSSEN and M. JuNG
}

H. Bahlsens Keksfabrik KG, Hannover, West Germany

\begin{abstract}
Certain foods such as nuts and treenuts are preferred media for aflatoxin-producing Penicillia and Aspergilli. About 50 per cent of the mouldy nuts examined contained aflatoxins in amounts of up to several hundred ppb. About 10-20 per cent of the mouldy grain products contained aflatoxins in amounts of up to $100 \mathrm{ppb}$. Aflatoxin was never detccted in jams, pickles or potato chips and crisps, even when mouldy.

$\Lambda$ flatoxin may penctrate several centimetres into foods in the course of only a few days. In general the aflatoxin content of the mycelium is higher than that of the food underneath and decreases with its distance from the mycclium; however, at a ccrtain depth the aflatoxin content increases again.

Even non-mouldy foods or raw materials may contain aflatoxins. Spores can be transferred by insects, cspecially flies, wasps and bees, or by birds to foods where the spores germinatc, produce mycclium, and aflatoxin is excreted. The mycclium can be removed afterwards by technological processes such as cxcavating, washing, salting, mixing, drying and heating. Such reasons may account for our findings of $5 \mathrm{ppb}$ aflatoxin $B_{1}$ in a sample of mould-free salami and $100 \mathrm{ppb}$ in mould-free ham. Seeds can contain aflatoxins by infection of the egg-cells of the flowering plants. Mould-frec peanut kerncls isolated from their shell contained 5 and 7 ppb aflatox in $B_{1}$, whilst the morc frequently occurring mouldy . kerncls in the shcll containcd up to $100 \mathrm{ppb}$. Mould-free peaches can contain mouldy kernels infected by toxin-producing Aspergilli and Penicillia. Their seeds contained up to $10 \mathrm{ppb}$ aflatoxin $B_{1}+B_{2}+G_{1}$.

During food processing there are many possibilities for mould infection. Blanched almonds for Marzipan and pcach or apricot seeds for Persipan should be processed immediately after blanching. We detected $3 \mathrm{ppb}$ aflatoxin $B_{1}$ and traces of $B_{2}$ and $G_{2}$ in blanched almonds kept for 3 days at $28^{\circ} \mathrm{C}$. The ready products 'Marzipan' (almond paste) and 'Persipan' (peach and/or apricot seed paste) can contain aflatoxins in amounts of up to $5 \mathrm{ppb}$.

55 samples of skim and whole milk powder supplied from 5 different German manufacturers were analysed. The milk powders of one supplier were practically free of aflatoxin $\mathrm{M}_{1}$, whilst nearly all samples of another supplier contained aflatoxin $\mathbf{M}_{1}$ in amounts ranging from traces to $4 \mathrm{ppb}$.

Pellets for hatched trouts contained $500 \mathrm{ppb}$ aflatoxin $\mathrm{B}_{1}$. We only detected traces of aflatoxin in the trouts' livers, whilst the faeces contained $500 \mathrm{ppb}$ aflatoxin $\mathrm{B}_{1}$. Canaries' feed contained $300 \mathrm{ppb}$ aflatoxin $\mathrm{B}_{1}$ and $125 \mathrm{ppb} \mathrm{B}_{2}$. Mouldy corn used as deer fodder contained $25 \mathrm{ppb}$ aflatoxin $\mathrm{B}_{1}$ and $25 \mathrm{ppb}$ aflatoxin $\mathrm{G}_{1}$.
\end{abstract}


Conditions for controlling aflatoxins in stored products and for preventing mould growth and toxin production are discussed. Storage conditions for certain raw materials are mentioned. The results of aflatoxin assays of hundreds of peanut samples harvested in different countrics in the last 5 years are intimated.

\section{INTRODUCTION}

The natural occurrence of aflatoxin in food is rare ${ }^{3}$. Results obtained on samples of different foodstuffs examincd at our laboratories indicate that those which do contain aflatoxins can be roughly divided into two groups. The first type is more or less contaminated with mould and/or spores, and in the second type neither mould nor spores can be detected.

\section{Spontaneously mouldy foodstuffs}

\section{RESULTS}

Experimentally, mould growth, with associated toxin production, has been reported in a wide variety of food products ${ }^{2}$. However, under normal (storage) conditions foods are not easily contaminated. Frank and Eyrich ${ }^{1}$ identified aflatoxin in only about 10 per cent of spontaneously mouldy foodstuffs. Bösenberg and Eberhardt ${ }^{5}$ examined 185 samples of mouldy foods taken in the course of half a year from three different supermarkets; only 3 of the 14 isolated $A$. flanus stems werc aflatoxin produccrs.

With regard to our observations on mouldy foods--meaning some mouldy spots on the food-there seems to be a preference for the aflatoxinproducing Aspergilli and Penicillia to grow and produce aflatoxin on special foods (Table I).

Although the number of mouldy foods that we analysed was not very large, one can see from Table $l$ that peanut, hazelnut and walnut kernels, and almonds when mouldy contain aflatoxin in more than 50 per cent of the samples and even show the highest amounts (up to $50000 \mathrm{ppb}$ ) of that toxin. This is in good agreement with the observations of Wheeler ${ }^{4}$, Frank $^{10}$, Frank and Eyrich ${ }^{1}$, Hesseltine ${ }^{13}$ and Bösenberg and Eberhardt ${ }^{5}$ who found that most of the tested groundnuts and groundnut products were contaminated with aflatoxin in extremely high amounts (up to $400 \mathrm{ppb}$ ). We found that single peanut and hazelnut kernels can be highly contaminated (30000 and $50000 \mathrm{ppb}$ aflatoxin $\mathrm{B}_{1}$ respectively). Cucullu ${ }^{8}$ reported single peanut kernels which contained from 300 up to 1100000 ppb aflatoxin $\mathrm{B}_{1}$.

Mouldy grain and corn and their processing products, also seem to be suitable media for aflatoxin production, although the detected aflatoxin contents were not much higher than $100 \mathrm{ppb}$. In the case of bread the tendency to form aflatoxins seems to depend upon the $\mathrm{pH}$ value of the medium ${ }^{6}$ and increases with the content of vitamin $\mathrm{B}_{1}{ }^{7}$, protein and salts. In mouldy bread samples with low protein, salt and vitamin $B_{1}$ content we analysed up to $25 \mathrm{ppb}$ aflatoxin $\mathrm{B}_{1}$ whilst in mouldy whole-meal bread and shredded wheat the aflatoxin content was more than 100 ppb. Frank and Eyrich ${ }^{1}$ 


\section{CONTROL OF AFLATOXINS IN THE FOOD INDUSTRY}

Table 1. Aflatoxin content in spontaneously mouldy foods

\begin{tabular}{|c|c|c|c|c|c|}
\hline Kind of mouldy food & $\begin{array}{l}\text { Number } \\
\text { of } \\
\text { samples }\end{array}$ & $\begin{array}{l}\text { Samples } \\
\text { containing } \\
\text { aflatoxin }\end{array}$ & $\begin{array}{l}\text { Percentage } \\
\text { (roughly) }\end{array}$ & $\begin{array}{l}\text { Aflatoxin } B_{1} \\
\text { content } \\
\text { (ppb) }\end{array}$ & $\begin{array}{l}\text { Kinds of mould } \\
\text { isolated, aflatoxin } \\
\text { producers are } \\
\text { marked with an } \\
\text { asterisk* }\end{array}$ \\
\hline \multicolumn{6}{|l|}{ 1. Oilseeds } \\
\hline Peanut kernels & 62 & 46 & 70 & $20-28000$ & $\begin{array}{l}\text { A. flavus* } \\
\text { M. mucedo }\end{array}$ \\
\hline Hazelnut kernels & 29 & 18 & 50 & $5-50000$ & $\begin{array}{l}\text { A. flavus* } \\
\text { M. mucedo }\end{array}$ \\
\hline Walnut kerncls & 12 & 3 & 25 & $5-35,500000$ & $\begin{array}{l}\text { A. flavus* } \\
\text { A. glaucus* }\end{array}$ \\
\hline Cashew nuts & 6 & 1 & - & 830 & A. flavus* \\
\hline Almonds, sweet & 23 & 19 & 80 & $39-4000$ & A. flavus* \\
\hline Sesame seed & 19 & 4 & 20 & $4-10$ & $\begin{array}{l}\text { A. flavus* } \\
\text { A. glaucus* }\end{array}$ \\
\hline $\begin{array}{l}\text { 2. Spices } \\
\text { Nutmeg }\end{array}$ & 13 & 3 & 20 & $5-15$ & $\begin{array}{l}P . \text { glaucum* } \\
M . \text { mucedo }\end{array}$ \\
\hline \multicolumn{6}{|l|}{ 3. Fruits and vegetables } \\
\hline Apples & 15 & 1 & - & 35 & $\begin{array}{l}\text { P. expansum* } \\
\text { P. species }\end{array}$ \\
\hline Oranges & 14 & 4 & 20 & $5-50$ & $\begin{array}{l}P . \text { expansum }{ }^{*} \\
P . \text { digitatum } \\
P . \text { citromyces } \\
\text { strictum var. } \\
\text { asymetricum }\end{array}$ \\
\hline Lemons & 18 & 3 & 15 & $20-60$ & $\begin{array}{l}P \text {. digitatum } \\
\text { P. species }\end{array}$ \\
\hline Peaches & 20 & 9 & 40 & $5-15$ & $\begin{array}{l}\text { P. glaucum* } \\
\text { A. glaucus* } \\
\text { A. flavus* } \\
\text { A. nidulans* } \\
\text { A. fumigatus }\end{array}$ \\
\hline Cherries & 8 & 1 & - & 5 & $\begin{array}{l}P . \text { expansum* } \\
P . \text { digitatum }\end{array}$ \\
\hline Apricots & 11 & 0 & 0 & 0 & $\begin{array}{l}\text { M. mucedo } \\
P . \text { glaucum } \\
\text { A. species }\end{array}$ \\
\hline Cucumber & 4 & 2 & - & 0 & P. species \\
\hline 4. Wheat, rye & 8 & 1 & n. & 5 & $\begin{array}{l}\text { A. flavus* } \\
\text { M. mucedo } \\
\text { P. species }\end{array}$ \\
\hline Wheat kernels & 7 & 3 & - & $10-15$ & A. flavus* \\
\hline Rye kernels & 2 & 1 & - & 15 & A. flavus* \\
\hline Maize & 3 & 1 & $\cdots$ & 25 & A. flavus* \\
\hline White bread & 18 & 2 & 10 & $20-25$ & P. glaucum* \\
\hline $\begin{array}{l}\text { German bread } \\
\text { 'Landbrot', made from } \\
80 \% \text { wheat flour } \\
20 \% \text { rye flour }\end{array}$ & 14 & 1 & 10 & 10 & A. glaucus* \\
\hline $\begin{array}{l}\text { Whole-meal wheat } \\
\text { bread }\end{array}$ & 18 & 4 & 20 & $5 \cdots 60$ & $P$. glaucum* \\
\hline $\begin{array}{l}\text { 'Müsli', made from } \\
\text { shredded wheat and } \\
\text { water ('organic food') }\end{array}$ & 14 & 4 & 25 & $20-120$ & $\begin{array}{l}\text { A. flavus* } \\
\text { P. species }\end{array}$ \\
\hline
\end{tabular}


Table 1 (cont.). Aflatoxin content in spontaneously mouldy foods

\begin{tabular}{|c|c|c|c|c|c|}
\hline Kind of mouldy food & $\begin{array}{l}\text { Number } \\
\text { of } \\
\text { samples }\end{array}$ & $\begin{array}{l}\text { Samples } \\
\text { containing } \\
\text { aflatoxin }\end{array}$ & $\begin{array}{l}\text { Percentage } \\
\text { (roughly) }\end{array}$ & $\begin{array}{l}\text { Aflatoxin } B_{1} \\
\text { content } \\
\text { (ppb) }\end{array}$ & $\begin{array}{l}\text { Kinds of mould } \\
\text { isolated, aflatoxin } \\
\text { producers are } \\
\text { marked with an } \\
\text { asterisk* }\end{array}$ \\
\hline \multicolumn{6}{|l|}{ 5. Cheese } \\
\hline Edam type & 11 & 0 & 0 & 0 & $\begin{array}{l}P \text {. glaucum } \\
\text { A. flarus }\end{array}$ \\
\hline $\begin{array}{l}\text { Cheese, lyophilized, } \\
\text { powdered }\end{array}$ & 11 & 0 & 0 & 0 & $\begin{array}{l}\text { P. glaucum } \\
\text { A. flavus }\end{array}$ \\
\hline 6. Meat products & & & & & \\
\hline Bacon & 10 & 2 & - & 1000,5000 & A. flarus* \\
\hline
\end{tabular}

found that 10 per cent of the mouldy whole-meal breads contained aflatoxin and also detected $7000 \mathrm{ppb} B_{1}$ and $1000 \mathrm{ppb} \mathrm{G}_{1}$ aflatoxin in a 'Müsli' made from shredded wheat and water, which was supposed to be eaten after standing for 3-5 days at $28-30^{\circ} \mathrm{C}$.

Fresh fruit such as peaches and cherrics (not apples) also secm to be preferred media for the growing of aflatoxin-producing fungi, although the excreted toxin amount is rather low (5-15 ppb). Oranges and lemons showed on their mouldy pecls aflatoxin contents of up to $50 \mathrm{ppb}$.

Vegetables similar to tomatoes for instance (not mentioned in Table l) often show mouldy spots but they are mostly contaminated by Mucor which normally does not produce aflatoxin; Aspergillus or Penicillium can only occasionally be isolated. The aflatoxin content, if any, is low.

In some mouldy foods such as jams, raisins, potato chips and crisps, and pickles we never detected any aflatoxin. With regard to jams this confirms the observation of Frank and Eyrich ${ }^{1}$. The high concentration of sucrose in jams and raisins, the sodium chloride content ( 2 per cent) of potato chips and crisps and the low $\mathrm{pH}$ value of 4 in pickles may prevent the germination of the spores and the formation of aflatoxins in these foodstuffs. Aspergillus growing on jams very often shows atypical famine forms.

From the mouldy foods mentioned in Table 1 we isolated 45 mould stems; 15 of them were $A$. flavus; 7 of them were $P$. glaucum; 5 of them were $M$. mucedo $; 4$ of them were A. glaucus and the rest were other different Penicillia and Aspergilli.

\section{Migration (diffusion) of aflatoxin into foodstuffs}

Aflatoxins excreted by the mycelium may decply diffuse into foodstuffs during a few days.

\section{(a) Coconut}

We inoculated the endosperm of a cross-sectioned coconut with $A$. flavus Linck and kept it at $35^{\circ} \mathrm{C}$ and 90 per cent relative humidity. The aflatoxin content was estimated two weeks after inoculation. The results are given in Table 2. 
Table 2. Diffusion of aflatoxin $\mathrm{B}_{1}$ from inoculated A. flavus into coconut endosperm. Three series: 14 days. $35^{\circ} \mathrm{C}$

\begin{tabular}{|c|c|c|c|c|c|}
\hline Tested component & $\begin{array}{l}\text { Depth } \\
(\mathrm{mm})\end{array}$ & $\begin{array}{r}\mathrm{Co} \\
\text { test } 1\end{array}$ & $\begin{array}{l}\text { t of afla } \\
\text { (ppb) } \\
\text { test } 2\end{array}$ & $\begin{array}{l}B_{1} \\
\text { test } 3\end{array}$ & Mycelium \\
\hline Spores & 0 & $*$ & * & 5 & - \\
\hline Mycelium & 2 & 20 & 250 & 11000 & + \\
\hline Endosperm & 10 & - & 85 & 12000 & t \\
\hline Endosperm & 20 & - & 835 & 38000 & - \\
\hline
\end{tabular}

* not detectable

Aflatoxin was identified in the spores in only one of the series. Toxin production in spores seems to depend upon the state of growth and other unknown circumstances. We tested the aflatoxin content of spores of $A$. flavus growing on a single walnut kernel every week and could not detect any aflatoxin in the first two weeks. In the third week, however, we analysed $500 \mathrm{ppm}$ !

The aflatoxin $\mathrm{B}_{1}$ content of the mycelium was different in the three series: 20,250 and $11000 \mathrm{ppb}$ respectively. In the endosperm, $10 \mathrm{~mm}$ below the mycelium, we found 85 and $12000 \mathrm{ppb}$ respectively; in a depth of $20 \mathrm{~mm}$ 835 and 38000 ppb were detected.

\section{(b) Whole-meal wheat bread}

A loaf of $14 \mathrm{~cm}$ length was cut in the middle into two pieces. One piece was inoculated with A. flavus Linck on the crust and the other one on the crumb, and then they were stored for 9 and 21 days respectively at $35^{\circ} \mathrm{C}$ and 90 per cent relative humidity. A considerable amount of the toxin migrated into the food to a depth of $7 \mathrm{~cm}$ (Tables $3 a$ and $3 b$ ).

The results show that aflatoxins are able to penetrate foods several centimetres in the course of only a few days. Migration of aflatoxin in cheese was reported by Frank ${ }^{10}$ and the Netherland Yeast and Alcohol Company ${ }^{12}$. Kiermeier and Behringer ${ }^{9}$ observed a penetration of $16 \mathrm{~cm}$.

Table $3 a$. Diffusion of aflatoxin $\mathrm{B}_{1}$. A. flavus inoculated on the crust of whole-meal bread. Two series; 9 and 21 days respectively, $35^{\circ} \mathrm{C}$

\begin{tabular}{lrrrr}
\hline $\begin{array}{c}\text { Tested } \\
\text { part }\end{array}$ & $\begin{array}{c}\text { Depth } \\
(\mathrm{mm})\end{array}$ & \multicolumn{2}{c}{$\begin{array}{c}\text { Content of aflatoxin } \mathrm{B}_{1} \\
(\mathrm{ppb})\end{array}$} & Mycelium \\
\hline Crust & 5 & 130 & 284000 & + \\
Crumb & 25 & 55 & 137000 & + \\
& 45 & 10 & 900 & + \\
& 65 & 35 & 4100 & + \\
& 70 & 420 & 45000 & - \\
\hline
\end{tabular}


Table $3 b$. Diffusion of aflatoxin $\mathbf{B}_{1}$. A. flavus inoculated on the crumb of wholemeal bread: 21 days, $35^{\circ} \mathrm{C}$

\begin{tabular}{cccc}
\hline $\begin{array}{c}\text { Tested } \\
\text { part }\end{array}$ & $\begin{array}{c}\text { Depth } \\
(\mathrm{mm})\end{array}$ & $\begin{array}{c}\text { Content of aflatoxin } \mathrm{B}_{1} \\
(\mathrm{ppb})\end{array}$ & Mycelium \\
\hline Crumb & 5 & 208000 & + \\
& 25 & 72000 & + \\
& 45 & 200 & - \\
Crust & 65 & 1400 & - \\
\hline
\end{tabular}

The mycelium of a mouldy food generally contains more aflatoxin than the food underneath. The aflatoxin content first decreases with its distance from the mycelium. However, at a certain depth the aflatoxin content increases again. This correlates with the observations of Frank ${ }^{10}$ in apple juice and of Kiermeier ${ }^{11}$ and Kiermeier and Behringer ${ }^{9}$ in cheeses (Table 4).

Table 4. Diffusion of aflatoxin $\mathrm{B}_{1}$ in Tilsiter checsc $^{9}$

\begin{tabular}{cc}
\hline $\begin{array}{c}\text { Depth } \\
(\mathrm{mm})\end{array}$ & $\begin{array}{c}\text { Aflatoxin } \mathrm{B}_{1} \\
(\mathrm{ppb} ; \text { mean } \bar{x})\end{array}$ \\
\hline 0 & 19 \\
20 & 4 \\
40 & 5 \\
60 & 2 \\
80 & 3 \\
100 & 5 \\
120 & 17 \\
\hline
\end{tabular}

We do not have a satisfactory explanation for this phenomenon. The rather high aflatoxin level at the end of the migration point may be a concentration effect. In the regions below the mycelium other and more slowly migrating ${ }^{10}$ substances which partly destroy the aflatoxins may be produced. Or, the aflatoxin itself may undergo unknown reactions during migration.

\section{Aflatoxin-containing food with no visible mould or spore infection} ferent.

Even non-mouldy food may contain aflatoxins: the reasons can be dif-

(a) Infection by insects

A. flavus as well as A. parasiticus can be transferred to foods by insects ${ }^{14}$, especially flies ${ }^{15}$ and birds ${ }^{16}$. The spores germinate, hyphae grow out and aflatoxin is excreted into foods such as ham, meat, bread and cheese. Afterwards the mycelium could be removed by technological processes such as cutting out, washing ${ }^{24}$, salting, mixing, drying and heating. This may account for our findings of $5 \mathrm{ppb}$ aflatoxin $\mathrm{B}_{1}$ in a sample of mould-free salami and $100 \mathrm{ppb}$ in a mould-free ham. 
(b) Infection of flowering plants

Mould spores can germinate on the stigmae of the pistil of flowering plants. The pollen tube grows down the style infecting the egg-cells in the embryo sac of the ovary (Figure 1) with mould and/or aflatoxin. Mould-free peanut kernels isolated from their shell contained 5 and $7 \mathrm{ppb}$ aflatoxin $\mathrm{B}_{1}$, whilst more frequently occurring mouldy kernels in the shell may contain more than $100 \mathrm{ppb}$ aflatoxin $\mathrm{B}_{1}$.

A. flavus and/or P. species infected kernels can be found in mould-free peaches. Their sceds can contain up to $10 \mathrm{ppb}$ aflatoxin $\mathrm{B}_{1}+\mathrm{B}_{2}+\mathrm{G}_{1}$.

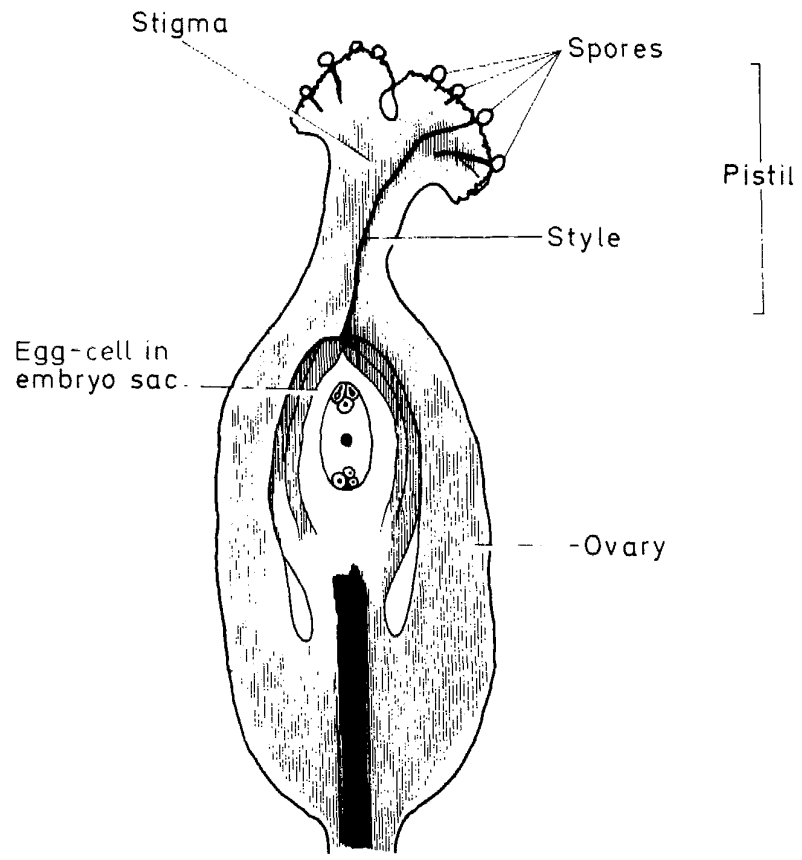

Figure 1 . Infection of the ovary by mould spores

\section{(c) Formation of aflatoxin during food processing}

There are two typical German sweet goods called Marzipan and Persipan. They are produced from almonds and apricot or peach seeds respectively, by mixing these with equal parts of sugar and drying the obtained mass at a temperature of $90-95^{\circ} \mathrm{C}$ to a water content of 17 per cent (Marzipan) or 20 per cent (Persipan).

In the production of Marzipan (almond paste) the almonds are liberated from their skin (seed-coat) by washing with hot water. In the production of Persipan (peach and/or apricot seed paste) the seeds are first liberated from their skin and their hydrocyanic acid content by watering for 24-48 hours at $12^{\circ} \mathrm{C}$. If these blanched almonds and peach and apricot seeds are not processed very soon after blanching an infection by mould spores and subsequent poisoning by aflatoxin can occur. (Blanched almonds kept for 
3 days at $28^{\circ} \mathrm{C}$ contained $3 \mathrm{ppb}$ aflatoxin $\mathrm{B}_{1}$ and traces of $\mathrm{B}_{2}$ and $\mathrm{G}_{2}$ ). This is one of the reasons why Marzipan and Persipan often contain aflatoxins. Moreover, with Persipan the rate of infection (10 out of 20 samples) ats the actual aflatoxin amount (up to $5 \mathrm{ppb}$ ) was much higher than with Marzipan where the rate of infection was 4 out of 16 samples and the actual aflatoxin amount did not exceed $2 \mathrm{ppb}$ (Table 5).

Table 5. Analysis of almond paste (A) and apricot seed paste (B)*

\begin{tabular}{|c|c|c|c|c|}
\hline & \multirow{2}{*}{$\begin{array}{c}\text { Number of } \\
\text { samples }\end{array}$} & \multicolumn{3}{|c|}{ Amount of aflatoxin (ppb) } \\
\hline & & $\mathrm{B}_{1}$ & $\mathrm{~B}_{2}$ & $\mathrm{G}_{1}$ \\
\hline A & 12 & $\dot{r}$ & 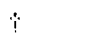 & $\dot{\varphi}$ \\
\hline A & 3 & traces & $i$ & $\dagger$ \\
\hline A & 1 & 2 & traces & $\therefore$ \\
\hline B & 10 & 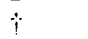 & $\vdots$ & $\dot{i}$ \\
\hline B & 1 & traces & $i$ & 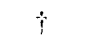 \\
\hline B & 3 & traces & traces & $\dot{i}$ \\
\hline B & 2 & 1 & $\dot{\dagger}$ & $\grave{i}$ \\
\hline B & 2 & 2,5 & $\dot{\dagger}$ & traces \\
\hline B & 1 & 3 & $\grave{i}$ & $\therefore$ \\
\hline B & 1 & 5 & $\therefore$ & $\dot{\dagger}$ \\
\hline
\end{tabular}

* Aflatoxin $\mathrm{G}_{2}$ was not detected in any of the samples

not detectable

(d) Aflatoxin in non-mouldy animal food products

Animal fodder--If animals receive mouldy fodder there is always the probability of aflatoxin intake and passage and/or transformation into human food.

Non-mouldy pellets, the feed for hatched trouts, contained $500 \mathrm{ppb}$ aflatoxin $B_{1}$. In the livers of the trouts fed with these pellets we detected only traces of aflatoxin, whilst the faeces contained $500 \mathrm{ppb}$ aflatoxin $\mathrm{B}_{1}$. However, there is always the possibility that the flesh may contain aflatoxins and tumours ${ }^{19-21}$.

In non-mouldy feed for birds, consisting of hemp, sun-flower seeds, millet, barley, maize and 'coloured' peanut kernels, we detected $300 \mathrm{ppb}$ aflatoxin $\mathrm{B}_{1}$ and $125 \mathrm{ppb} \mathrm{B}_{2}$. Aflatoxin-containing feed of birds may be one of the reasons for the kidney and liver cancers very often obscrved in canaries.

Mouldy corn which was to have been used as stag or deer fodder contained $25 \mathrm{ppb}$ aflatoxin $\mathrm{B}_{1}$ and $25 \mathrm{ppb}$ aflatoxin $\mathrm{G}_{1}$.

Milk powder-If cows are fed with aflatoxin-containing fodder, less than 5 per cent of the aflatoxin $\mathrm{B}$ content is converted to aflatoxin $\mathrm{M}^{23}$, which is excreted with the milk.

During the period February to August 1972 we tested 27 samples of spray dried skim milk powder and 28 samples of spray dried wholc milk powder. These samples were supplied by five different German manufacturers. The results are shown in Table 6.

Supplier D was the only one whose samples-with the exception of onedid not contain any aflatoxin $M_{1}$. In contrast practically all samples from supplier A contained aflatoxin $M_{1}$ and even showed amounts of up to $4 \mathrm{ppb}$. 
Table 6. Analysis of aflatoxin $\mathrm{M}_{1}$ content of commercial milk powders from five different German manufacturers

\begin{tabular}{|c|c|c|c|c|c|c|c|c|c|c|}
\hline \multirow[t]{2}{*}{ Manufacturer } & \multicolumn{2}{|c|}{$\begin{array}{l}\text { Number of } \\
\text { samples }\end{array}$} & \multicolumn{2}{|c|}{$\begin{array}{c}\text { Aflatoxin } \mathrm{M}_{1} \\
\text { not detected }\end{array}$} & \multicolumn{2}{|c|}{$\begin{array}{l}\text { Aflatoxin } \\
\text { traces }\end{array}$} & \multicolumn{2}{|c|}{$\begin{array}{l}\text { Aflatoxin } M_{1} \\
1 \mathrm{ppb}\end{array}$} & \multicolumn{2}{|c|}{$\begin{array}{l}\text { Aflatoxin } \mathrm{M}_{1} \\
2-4 \mathrm{ppb}\end{array}$} \\
\hline & $\mathrm{S}^{*}$ & W: & $\mathrm{S}$ & W & $\mathrm{S}$ & W & $\mathrm{S}$ & $\mathrm{W}$ & $S$ & W \\
\hline$\Lambda$ & 8 & 7 & 1 & 1 & 4 & 3 & 1 & 2 & 2 & 1 \\
\hline B & - & 14 & $\therefore$ & 5 & $\ldots$ & 9 & $\ldots$ & - & - & - \\
\hline C & 6 & - & 3 & - & 1 & - & 2 & - & - & - \\
\hline D & 5 & - & 4 & - & 1 & $\ldots$ & 一 & - & - & - \\
\hline $\mathrm{E}$ & 8 & 7 & 2 & 3 & 5 & 4 & 1 & - & - & - \\
\hline
\end{tabular}

* $\mathrm{S}-$ skim milk powder

$\mathrm{W}$ - whole milk powder

These observations confirm the findings of Neumann-Kleinpaul and Terplan ${ }^{17}$. They analysed 80 samples of spray and drum dried skim and whole milk powders, and 56 samples of dricd milk for dietary purposes, babies and children, and found aflatoxin $M_{1}$ contents of between 0.67 and $2 \mathrm{ppb}$ in 6 per cent of the samples. Purchase and Vorster ${ }^{18}$ investigated fluid milk samples for aflatoxin $M_{1}$ content and found that 2 out of 21 contained about $0.16 \mathrm{ppb}$ and 3 contained traces.

The above results have a practical bearing on the feeding of animals and men. There is a danger of aflatoxin intake from animal food for human consumption if the animals receive mouldy fodder. The absence of aflatoxins cannot be guaranteed when the industrially produced fodder is not free of aflatoxins and the farmers, who often give mouldy feed to the animals, do not know about the dangerous effects of mycotoxins.

\section{DISCUSSION}

Although the natural occurrence of aflatoxins is rare there are many possibilities by which humans and animals can be harmed by unconscious intake of mycotoxins with their food. Aflatoxins occur in the spores, in the mycelium, or as separate exotoxins in the nutritive medium of the fungi, i.e. the food.

Certain special foods such as peanuts, almonds, treenuts, wheat, rye and maize kernels, or whole-meal products seem to be preferred media for the growing of aflatoxin-producing fungi. On the other hand, fruit and vegetables if contaminated contain aflatoxins in only small amounts, if at all. Aflatoxins were never detected in some naturally mouldy foods such as jams, potato chips and crisps, and pickles.

We found that the following conditions for storing raw materials and foods effectively controlled aflatoxins and prevented mould from growing (and toxin production).

Relative humidity $<65$ per cent; mould fungi require a relative humidity of 65 per cent.

Temperature $<10^{\circ} \mathrm{C}$. Mould fungi are able to grow at $-3^{\circ} \mathrm{C}$, however, aflatoxin production induced by Aspergillus and Penicillium ceases at 13 and $4^{\circ} \mathrm{C}$, respectively. 
Moisture content $<12$ per cent; aflatoxin synthesis can commence with 12 per cent substrate humidity.

This is the reason for our proposal of very closely kept storage conditions for some raw materials which are easily susceptible to mould growth and fflatoxin formation (Table 7).

Table 7. Storage conditions for some raw materials which are susceptible to mould growth and aflatoxin formation; storage time 6 months

\begin{tabular}{lccc}
\hline Raw material & $\begin{array}{c}\text { Substrate humidity } \\
\left(\% \mathrm{H}_{2} \mathrm{O}\right)\end{array}$ & $\begin{array}{c}\text { Temperature } \\
\left({ }^{\circ} \mathrm{C}\right)\end{array}$ & $\begin{array}{c}\text { Relative humidity } \\
(\% \varphi)\end{array}$ \\
\hline $\begin{array}{l}\text { Wheat kernels } \\
\text { Rye kernels } \\
\text { Maize kernels }\end{array}$ & $<15$ & 6 & 60 \\
$\begin{array}{l}\text { Peanut kernels } \\
\text { Cashew kernels }\end{array}$ & 6 & 4 & $<65$ \\
$\begin{array}{l}\text { Hazelnut kernels } \\
\text { Walnut kernels }\end{array}$ & 6 & 8 & $<65$ \\
Almonds & 6 & 8 & $<65$ \\
\hline
\end{tabular}

Tables $8 a$ and $8 b$ show how far harvesting and storage conditions ('aflatoxin control') may influence the quality of exported peanuts. We never found aflatoxins in Chinese samples. The peanuts are grown in the northern part of China and are harvested during a 3 month period in which there is usually no rain fall. The quality of peanuts from the Sudan has much improved during the course of the last few years. Peanuts from the USA always had particular samples with aflatoxin amounts above $100 \mathrm{ppb}$. Peanuts from

Table 8a. Aflatoxin content in peanut kernels of different provenances; 1970

\begin{tabular}{lcc}
\hline Provenance & $\begin{array}{c}\text { Number of } \\
\text { samples }\end{array}$ & $\begin{array}{c}\text { Aflatoxin } \mathrm{B}_{1} \\
(\mathrm{ppb})\end{array}$ \\
\hline South Africa & 543 & $*$ \\
& 1 & 20 \\
USA & 2 & 10 \\
& 6 & 5 \\
Sudan & 1 & 5 \\
& 54 & $*$ \\
Angola & 1 & 10 \\
& 1 & $*$ \\
& 19 & 40 \\
Brazil & 1 & $625 \mathrm{~B}_{1}$ \\
China & 1 & $180 \mathrm{~B}_{2}$ \\
Malawi & & $315 \mathrm{G}_{1}$ \\
Senegal & 1 & $40 \mathrm{G}_{2}$ \\
\hline not detectable & 1 & $*$ \\
\end{tabular}


South Africa were practically free of aflatoxins because of the intensive hand picking and the hard control work done by the Oil Seeds Control Board. Their toxin content never exceeded $20 \mathrm{ppb}$.

Table $8 b$. Aflatoxin content in peanut kernels of different provenances; 1971

\begin{tabular}{lrr}
\hline Provenance & $\begin{array}{c}\text { Number of } \\
\text { samples }\end{array}$ & $\begin{array}{c}\text { Aflatoxin } B_{1} \\
(\mathrm{ppb})\end{array}$ \\
\hline China & 8 & $*$ \\
Sudan & 12 & $*$ \\
& 1 & 5 \\
South Africa & 1 & 20 \\
& 258 & $*$ \\
USA & 1 & 20 \\
& 35 & 5 \\
& 1 & 10 \\
& 1 & 625 \\
\hline
\end{tabular}

* not detectable

The food industry and farmers should observe all conditions attached to the so-called (food) processing hygiene ${ }^{22}$. This includes sanitation of raw materials and their manufacturing. Mouldy foodstuff should neither be used for the production of human food nor for feeding animals. Otherwise there can be no guarantee given that the food products are free from aflatoxins.

\section{REFERENCES}

${ }^{1}$ H. K. Frank and W. Eyrich, Z. Lebensm. Untersuch. Forsch., 138, 1 (1968).

2 L. A. Goldblatt, Aflatoxin: scientific background, control and implications, p. 23, Academic Press, New York, London (1969).

3 J. C. Ayres, H. S. Lillard and D. A. Lillard, Food Technol. 24, No. 2, 58 (1970).

4 B. Wheeler, Irish J. Agr. Res., 8, 172 (1969).

${ }_{5}$ H. Bösenberg and E. Eberhardt, Med. Ernähr., 10, 12 (1969).

${ }^{6}$ E. Welte, Arch. Hyg., 24, 84 (1895).

7 E. Hanssen and G. Hagedorn, Z. Lebensm. Untersuch. Forsch., 141, 129 (1969).

8 A. F. Cucullu, L. S. Lee, R. Y. Mayne and L. A. Goldblatt, J. Am. Oil Chemists' Soc., 43, 89 (1966).

9 F. Kiermeier and G. Behringer, Z. Lebensm. Untersuch. Forsch., 148, 72 (1972).

10 H. K. Frank, Arch. Lebensmittelhyg.,17, 237 (1966).

11 F. Kiermeier, Z. Lebensm. Untersuch. Forsch., 144, 293 (1970).

12 Netherland Yeast and Alcohol Company, Delft, Untersuchungsbericht über Mykotoxine (Research Report on Mycotoxins), (26 April 1966).

13 C. W. Hesseltine, O. L. Shotwell, J. J. Ellis and R. D. Stubblefield, Bacteriol. Rev., 30, 795 (1966).

14 C. Toumanoff, Ann. Parasitol. Humaine et Comparée, 9, 462 (1931).

15 F. Senser, Deut. Lebensm. Rundschau, 63, 140 (1967).

16 L. A. Goldblatt, Pure and Appl. Chem.. 35, 15 (1973).

17 A. Neumann-Kleinpaul and G. Terplan, Arch. Lebensmittelhyg., 23, 128 (1972).

18 I. F H. Purchase and L. J. Vorster, S. African Med. J., 42, 219 (1968).

19 Lancet, 654 (1964).

20 W. Wunder and H. Otto, Naturwissenschaften, 56, 352 (1969). 


\section{E. HANSSEN AND M. JUNG}

21 J. E. Halver, Mycotoxins in foodstuffs, p. 209 (ed. G. N. Wogan), MIT Press, Cambridge, Mass. (1965).

$2^{2}$ E. Hanssen, Fertigungshygiene, 27, Diskussionstagung Forschungskreis der Ernährungsindustrie, p. 9, Hannover (1969).

23 C. R. Brewington and J. L. Weihrauch, J. Dairy Sci., 53, 1509 (1970).

24 T. C. Tung and K. H. Ling, J. Vitaminol., 14, 48 (1968). 